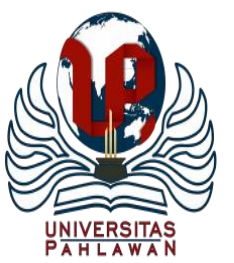

Jurnal Abdidas Volume 1 Nomor 3 Tahun 2020 Halaman 165 - 171

JURNAL ABDIDAS

Community Development Service on Educational and Health Sciences

http://abdidas.org/index.php/abdidas

\title{
Adaptasi Pendampingan Pengelolaan Sampah di Masa Pandemi Covid-19 melalui Web Training Kreatifitas Produk Olahan Sampah
}

\author{
Amrizarois Ismail $^{1}$, Mi Retno Susilorini ${ }^{2}$, Dhiyan Krishna Wardhani ${ }^{3}$, Lintang Jata Angghita ${ }^{4}$ \\ Universitas Katolik Soegijapranata Semarang, Jawa Tengah, Indonesia ${ }^{1,2,3,4}$ \\ E-mail : amrizarois@unika.ac.id ${ }^{1}$ susilorini@unika.ac.id ${ }^{2}$ dhiyan.krishna@unika.ac.id ${ }^{3}$ \\ lintang.jata@unika.ac.id ${ }^{4}$
}

\begin{abstract}
Abstrak
Dalam masa pandemi COVID-19 ini, persolan pengelolaan sampah semakin besar. Pembatasan Kegiatan Masyarakat (PKM) di Kota Semarang mengakibatkan berkurangnya aktivitas masyarakat di luar rumah yang juga turut mendorong meningkatnya produksi sampah di dalam rumah tangga. Ketika pembatasan sosial diberlakukan, pelatihan dan seminar menjadi hal yang sulit untuk dilaksanakan. Berangkat dari hal tersebut, diperlukan alternatif metode baru dalam berkegiatan. Metode yang digunakan dalam kegiatan pengabdian masyarakat ini adalah metode demonstrasi. Sedangkan dalam analisis hasil kegiatan, metode yang digunakan adalah metode kualitatif eksperimental. Kegiatan web training kreatifitas hasil olahan sampah yang dilakukan RIL UNIKA Soegijapranata Semarang bekerja sama dengan Bank Sampah Bina Karya Sejahtera merupakan bentuk adaptasi kegiatan yang mampu menjadi alternatif bagi bank sampah untuk tetap menjalankan kegiatan peningkatan kapasitas SDM di masa pandemi COVID-19. Hal tersebut ditunjukan dengan adanya respon positif dari mayoritas peserta web training yang menunjukan efektifitas web training dan kegiatan yang berbasis digital lainya.
\end{abstract}

Kata kunci: web training, sampah, 3R, bank sampah, COVID-19, RIL

\begin{abstract}
During the COVID-19 pandemic, the problem of waste management was even greater. Restrictions on Community Activities (PKM) in the city of Semarang resulted in reduced community activities outside the home which also contributed to increased production of garbage in the household. when social restrictions are treated, training and seminars become difficult to implement. Departing from this, new methods of alternatives are needed in activities. The method used in this community service activity is the Demonstration method. Whereas in analyzing the results of activities, the method used is an experimental qualitative method. Creative Waste Processed Web training activities conducted by RIL UNIKA Soegijapranata Semarang in collaboration with the Trash Bank Bina Karya Sejahtera is a form of activity adaptation that can be an alternative for the Trash Bank to continue carrying out HR capacity building activities during the COVID 19 Pandemic. positive from the majority of web training participants who show the effectiveness of web training and other digital-based activities.
\end{abstract}

Keywords: web training, garbage, 3R, garbage bank, COVID-19, RIL

Copyright (c) 2020 Amrizarois Ismail, MI Retno Susilorini, Dhiyan Krishna Wardhani, Lintang Jata Angghita

$\triangle$ Corresponding author :

Address : Pawiyatan Luhur IV/1, Bendan Dhuwur, Semarang

Email : amrizarois@unika.ac.id

Phone : +6285713989552

ISSN 2721-9224 (Media Cetak)

ISSN 2721- 9216 (Media Online)

DOI: https://doi.org/10.31004/abdidas.v1i3.38 


\section{PENDAHULUAN}

Secara global, jumlah sampah plastik dunia diperkirakan akan mencapai 2,2 miliar ton pada tahun 2025. Di Indonesia sendiri, produksi sampah plastik sendiri tiap tahunya telah mencapai 64 juta ton, sedangkan sampah plastik yang bocor ke laut melalui sungai sendiri 3,2 juta ton tiap tahunnya (Puspita, 2018). Keberadaan sampah plastik yang tiap tahun bertambah dan belum terpecahkan semakin menjadi ancaman serius bagi manusia dan lingkungan ekosistem terlebih saat memasuki masa pandemi COVID -19.

Dalam masa pandemi COVID-19 ini, persolan pengelolaan sampah semakin besar. Kebijakan Pembatasan Sosial Skala Besar (PSSB) di Jakarta serta daerah lainnya di Indonesia dan Pembatasan Kebiatan Masyarakat (PKM) di Kota Semarang mengakibatkan berkurangnya aktivitas masyarakat di luar rumah. Hal tersebut mendorong produksi sampah di dalam rumah tangga. Kegiatan niaga seperti pemenuhan kebutuhan pokok, bahkan kebutuhan makan sehari-hari dilakukan melalui media daring. Setidaknya ada 5 bungkus plastik yang dihasilkan ketika masyarakat memesan makanan secara daring ketika bulan Ramadhan seperti saat ini.

\section{Pemesanan makanan daring serta} perlindungan diri ketika terjadi pandemik seperti sekarang ini telah meningkatkan jumlah sampah plastik yang ada. Volume sampah secara umum menurun sebesar 0,7\%, terjadi di Bandung. Akan tetapi, terjadi pergeseran kenaikan sampah dari rumah tangga karena kebijakan untuk tetap tinggal di rumah (Muhammad Fauzi Ridwan, 2020).
Pakar Kebijakan Limbah dari Health Care Without Harm, Ruth Stinger, menyampaikan adanya trend peningkatan penggunaan sampah (khususnya sampah yang tidak bisa terurai seperti plastik sekali pakai/singgle use plastic) mengalami peningkatan yang cukup signifikan, terutama saat menhadapi wabah COVID-19 (Yudha Manggala P Putr, 2020).

Sama halnya yang disampaikan pemilik Tenleytown Trash (Perusahaan Pengolah Sampah di Amerika), Barley Shapiro, sebagaimana dikutip CNN Business menyampaikan peningkatan sampah yang masuk layanan pengolahan sampah di Amerika mengalami peningkatan sebayak 30\% selama wabah COVID-19 ini. Kondisi tersebut juga terjadi di Indonesia, ketika masyarakat dipaksa untuk terus berada di dalam rumah dikarenakan pandemi COVID-19, ternyata pola konsumtif masyarakat terhadap makanan dan barang kebutuhan lainya juga meningkat, sehingga sampah dari sisa konsumsi tersebut juga meningkat signifikan, hal tersebut diperparah dengan berhentinya kegiatan pengelolaan sampah (3R) berbasis bank sampah.

\section{METODE}

Metode yang digunakan dalam kegiatan pengabdian masyarakat ini adalah metode demonstrasi. Metode demonstrasi adalah metode penyampaian informasi dengan cara penyajian dan memperagakan atau mempertunjukkan suatu proses, situasi atau benda tertentu yang sedang dipelajari baik dalam bentuk sebenarnya maupun dalam bentuk tiruan yang yang ditampilkan pada khalayak publik (Stauri et al., 2015). 
Sedangkan dalam analisis hasil kegiatan, metode yang digunakan adalah metode kualitatif eksperimental. Penelitian eksperimen merupakan penelitian yang dilakukan dengan melakukan manipulasi yang bertujuan untuk mengetahui akibat manipulasi terhadap perilaku individu yang diamati (Sulistyaningsih, 2011). Manipulasi yang dilakukan dapat berupa situasi atau tindakan tertentu yang diberikan kepada individu atau kelompok dan setelah itu dapat dilihat pengaruhnya. Eksperimen ini dilakukan untuk mengetahui efek yang ditimbulkan dari suatu perlakuan yang diberikan secara sengaja oleh peneliti.

Kegiatan web training kreatifitas produk olahan sampah merupakan kegiatan training atau pelatihan pengelolaan sampah rumah tangga atau sejenis sampah rumah tangga yang diadakan dengan menggunakan media virtual, yaitu menggunakan media sosial berbasis internet dengan mengandalkan fitur utamanya berupa audio visual.

Kegiatan ini merupakan kegiatan pengabdian masyarakat program studi Rekayasa Infrastruktur dan Lingkungan (RIL) Universitas katolik (UNIKA) Soegijapranata Semarang bekerjasama dengan Bank Sampah Bina Karya Sejahtera (BS BKS) Rw IV, Kelurahan Tinjomoyo, Kecamatan Banyumanik, Semarang.

Adapun tahapan kegiatanya adalah sebagaai berikut:

\section{Tahapan Persiapan}

Pada tahap ini merupakan tahapan awal dimana tahapan ini dijalankan dalam rangka mempersiapkan segala sesuatu terkait kegiatan agar dapat berjalan lancar. Beberapa kegiatan yang dilaksanakan adalah membentuk kepanitiaan dan pembagian tugasnya, membuat perencanaan meliputi waktu dan tempat atau media kegiatan, menyusun konsep dan metode kegiatan, menentukan dan melengkapi peralatan serta bahan yang akan digunakan, dan lain sebagainya.

\section{Tahap Pelaksanaan}

Pada tahap ini dilakukan pelatihan yang diberikan kepada peserta training dengan menggunakan metode demonstrasi. Waktu pelaksanaan adalah hari Minggu, 28 juni 2020, menggunakan media aplikasi meeting virtual "Zoom". Adapun topik yang disampaikan adalah.

a. Pelatihan Pembuatan Lampion COVID-19 Pembuatan lampu atau lampion hias, dengan pemateri 1) Dwi Indarto dan 2) Yohanes Budiman. Lampion yang diberi nama Lampion Corona ini terbuat dari sampah gelas bekas minuman kemasan yang disusun sedemikian rupa sehingga terbentuklah lampion bulat yang menyerupai lampu disko dengan duri-duri menyerupai inang virus Corona.

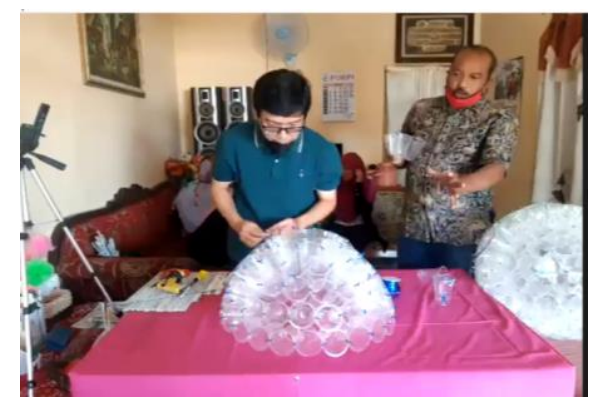

Gambar 1. Foto Demonstrasi Pembuatan Lampion Corona 
b. Pelatihan Pembuatan Fas dan Bunga.

Pembuatan Fas/pot bunga dari sampah bekas koran dan majalah dan bunga dari plastik kresek bekas yang disusun sedemikian rupa hingga terbentuklah pruduk tersebut, materi yang kedua ini disampaikan oleh 1) Sri Handini dan 2) Kurniati Supraptiningsih.

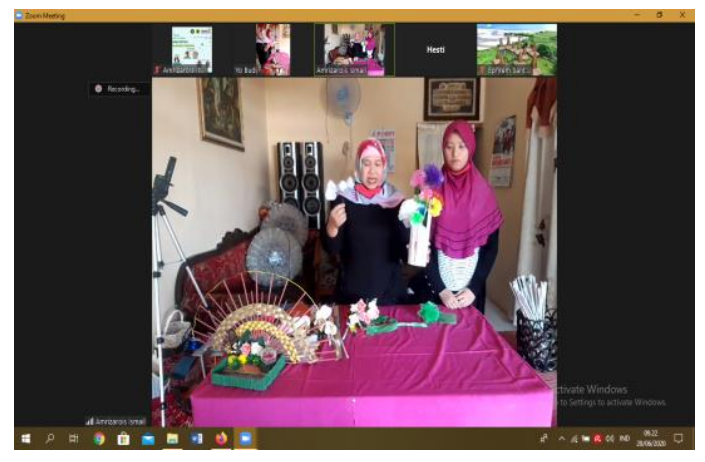

Gambar 2. Foto Demonstrasi Pembuatan Fas dan Bunga

\section{Tahap Tanya Jawab dan Diskusi}

Tahapan ini dilaksanakan setelah tahapan pelaksanaan dalam hal ini adalah penyampaian materi atau topik pelatihan secara keseluruhan telah disampaikan. Pada tahap ini pembawa acara akan mengalokasikan waktu dan memberikan kesempatan kepada peserta pelatihan untuk menyampaikan pertanyaan, tanggapan atau tambahan terhadap topik dan proses demonstrasi yang disampaikan pada tahapan sebelumnya. Dalam kegiatan ini setidaknya ada beberapa pertanyaan yang disampaikan peserta, diantaranya adalah:

a. Apakah ukuran lampu lampion korona dapat diperkecil
Jawab: Bisa diperkecil berdasarkan ketersediaan bahan, ukuran ruang yang akan digunakan untuk memasang, serta selera masing-masing.

b. Bagaimana pangsa pasar produk hasil kreatifitas olahan sampah seperti produck tersebut?

Jawab: Pangsa pasar cukup prospektif, mengingat sekarang banyak tempattempat berkumpul komunitas semisal Kafe dan Resto untuk sekedar melepas penat dan mungkin bekerja. Kafe tersebut umumnya memerlukan benda hasil kreatifitas atau seni (art) untuk memperindah ruangan, dan itu bisa dijadikan prospek pasar yang cukup menarik untuk produk art semacam ini.

\section{Tahapan Penutupan}

Pada kegiatan ini peserta, pemateri dipandu oleh pembawa acara akan melihat kesimpulan dari awal sampai akhir kegiatan untuk dapat melihat kelebihan dan kekurangan, saran serta hal menarik dari kegiatan ini. Sebelum penyampaian kesimpulan dilaksanakan, terlebih dahulu peserta diarahkan oleh pembawa acara untuk mengisi beberapa pertanyaan yang telah tertera pada formulir angket digital yang telah dipersiapkan panitian. 


\section{HASIL DAN PEMBAHASAN}

\section{Web Training sebagai Bentuk Adaptasi Pendampingan Pengelolaan Sampah di Masa Pandemi}

Seperti yang telah disampaikan sebelumnya bahwa kegiatan pengelolaan sampah di bank sampah sempat menemui kendala operasional di masa pandemi COVID-19. Hal ini dikarenakan aturan pembatasan sosial yang berlaku, sehingga bank sampah tidak dapat mengumpulkan masyarakat khususnya nasabah guna melakukan pengumpulan sampah hingga kegiatan pengembangan sumber daya manusia seperti diskusi, seminar dan pelatihan.

Semarang sendiri, dalam rangka menanggulangi penyebaran COVID-19 turut memberlakukan aturan Pembatasan Kegiatan Masyarakat (PIKM) yang juga membatasi jumlah masyarakat dalam berkerumun. Hal ini tentu mempengaruhi efektifikats kegiatan bank sampah seperti di atas. Untuk itu diperlukan berbagai alternatif, agar bank sampah tetap mampu menjalankan fungsinya, khususnya dalam pengembangan sumber daya manusia dalam upaya pengelolaan sampah, dalam hal ini pelatihan atau training.

Kegiatan web training yang telah dilakukan di atas sendiri bisa menjadi alternatif solusi bank sampah untuk dapat menjalankan pelatihan atau training, hal ini dapat dilihat dari beberapa hal,

\section{Atensi Peserta}

Kegiatan web training kreatifitas produk olahan sampah ini dilaksanakan untuk internal nasabah BS BKS Tinjomoyo Rw VI. Dari jumlah keseluruhan nasabah yang mencapai 50 orang, setidaknya 30 diantaranya telah mengikuti web training tersebut. Peserta merupakan warga Kelurahan Tinjomoyo Rw 6 yang juga menjadi nasabah Bank Sampah Bina Karya Sejahtera yang terdiri atas 7 Laki-laki dan 23 Perempuan.

2. Respon Peserta

Selain keikutsertaan, hal yang dapat dijadikan tolak ukur keefektifan web training ini adalah respon peserta terhadap pelatihan. Respon peserta ini merupakan luaran atau hasil akhir kegiatan yang mana dapat digunakan sebagai tolok ukur seberapa besar manfaat palatihan terhadap peserta. Adapun respon peserta terhadap web training ini dapat dilihat dari hasil angket peserta sebagai berikut:

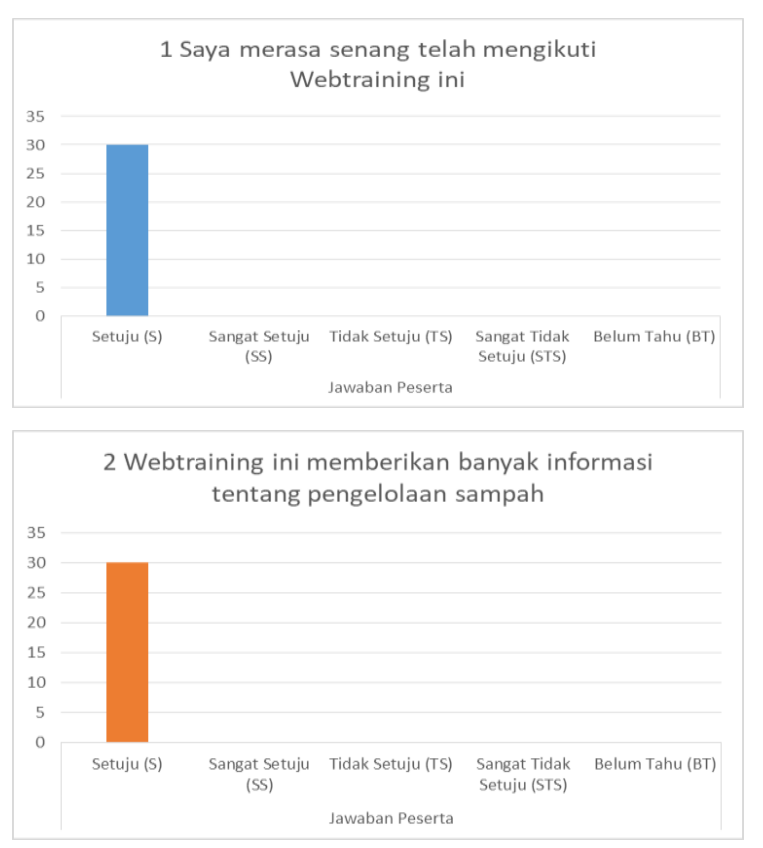




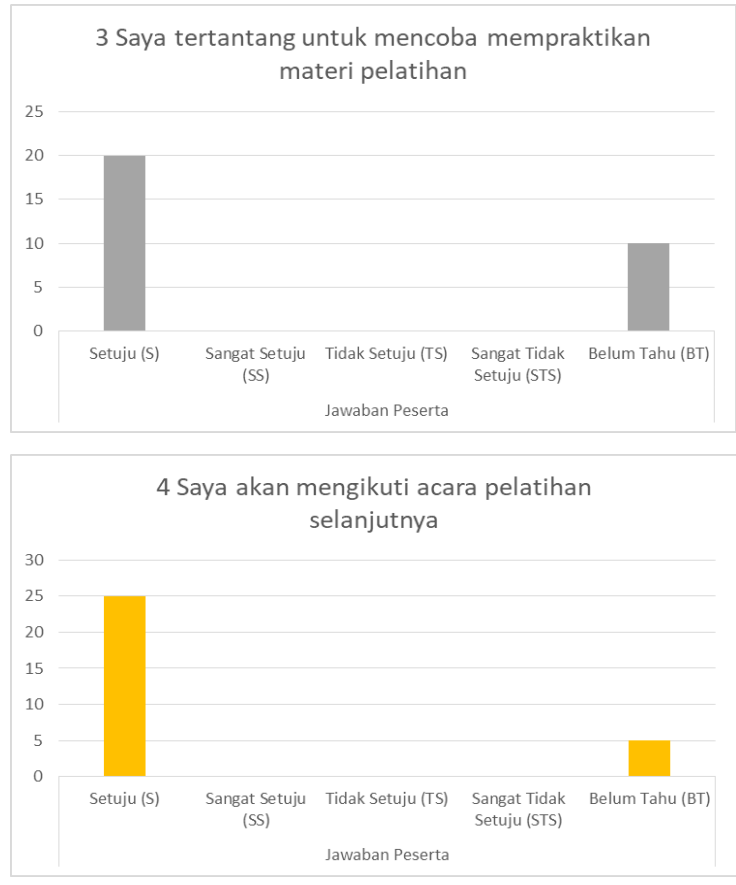

Gambar 1. 3 Grafik Respon Peserta Web Training

Gambar menunjukan respon peserta terhadap web training kreatifitas produk olahan sampah. Adapun hasil menunjukan dari 4 pertanyaan tentang web training, sebagai mana tertera di atas, hampir sebagian besar peserta memberikan respon positif terhadap web training. Diantaranya adalah 30 peserta menyatakan senang dengan adanya web training ini, 30 peserta menyatakan web training ini memberikan banyak informasi, 20 peserta menyatakan tertarik untuk mempraktikan materi pelatihan, dan 25 peserta menyatakan akan mengikuti acara web training selanjutnya.

Sedangkan dari keseluruhan pertanyaan, hanya 5 peserta yang menunjukan respon belum tahu untuk mencoba mempraktikan dan 5 peserta merespon belum tahu untuk mengikuti web training selanjutnya.
Melihat dari mayoritas respon tersebut, dapat disimpulkan bahwa metode web training secara virtual mampu menjadi alternatif kegiatan bank sampah, terutama kegiatan peningkatan kapasitas sumber daya manusia terhadap upaya pengelolaan sampah di masa pandemi COVID-19.

\section{SIMPULAN}

Dari kegiatan dan hasil pembahasan di atas dapat disimpulkan bahwa kegiatan web training kreatifitas hasil olahan sampah yang dilakukan RIL UNIKA Soegijapranata Semarang bekerjasama dengan Bank Sampah Bina Karya Sejahtera telah berjalan cukup maksimal dengan jumlah peserta sesuai target yaitu 30 peserta.

Web training merupakan bentuk adaptasi kegiatan yang mampu menjadi alternatif baru bagi bank sampah untuk tetap menjalankan kegiatan peningkatan kapasitas SDM dalam upaya pengelolaan sampah dimasa Pandemi COVID-19. Hal tersebut ditunjukan dengan adanya respon positif dari mayoritas peserta web training yang menunjukan efektifitas web training dan kegiatan yang berbasis digital lainya.

\section{UCAPAN TERIMA KASIH}

Terselenggaranya kegiatan pengabdian kepada masyarakat dengan topik Web Training Kreatifitas Produck Olahan Sampah tidak lepas dari dukungan Program Studi Rekayasa Infrastruktur dan Lingkungan, LPPM Universitas Katolik Soegijapranata dan Bank Sampah Bina Karya Sejahtera. Oleh karena itu, melalui kesempatan ini Tim Pengabdian Masyarakat Program Studi Rekayasa Infrastruktur dan 
171 Adaptasi Pendampingan Pengelolaan Sampah Di Masa Pandemi COVID-19 Melalui Web Training Kreatifitas Produk Olahan Sampah - Amrizarois Ismail, MI Retno Susilorini, Dhiyan Krishna Wardhani, Lintang Jata Angghita

DOI: https://doi.org/10.31004/abdidas.v1i3.38

Lingkungan Unika Soegijapranata mengucapkan terima kasih atas dukungan penuh sehingga kegiatan pengabdian kepada masyarakat ini dapat berjalan dengan lancar.

\section{DAFTAR PUSTAKA}

Muhammad Fauzi Ridwan. (2020, April 2). Pandemi COVID-19, Sampah Komersil di Bandung Berkurang. Republika. https://republika.co.id/berita/q83ush459/pand emi-COVID19-sampah-komersil-di-

bandung-berkurang

Puspita, S. (2018, August). Indonesia Penyumbang Sampah Plastik Terbesar Kedua di Dunia. Kompas.Com,

https://megapolitan.kompas.com/read/2018/0 $8 / 19 / 211$.

Stauri, S., Wantiyah, \& Rasni, H. (2015). Pengaruh Pendidikan Kesehatan Metode Demonstrasi Terhadap Tingkat Pengetahuan Dan Motivasi Penggunaan Alat Pelindung Diri (Apd) Pada Petani Desa Wringin Telu Kecamatan Puger Kabupaten Jember. EJurnal Pustaka Kesehatan.

Sulistyaningsih. (2011). Metodologi Penelitian Kebidanan:Kuantitatif-Kualitatif. In Metodologi Penelitian Kebidanan:KuantitifKualitatif.

Yudha Manggala P Putr. (2020, April 4). Pakar: Tren Plastik Sekali Pakai Naik Selama Pandemi. Republika. https://republika.co.id/berita/q87zt4284/pakar -tren-plastik-sekali-pakai-naik-selamapandemi 